\title{
Identification of future activities of enterprises regarding the growth of innovativeness
}

Prof. Eulalia Skawińska University of Zielona Gora

Prof. Romuald I. Zalewski Poznan University of Economics Gniezno College 'Milenium'

\section{Introduction}

During the global crisis in the world economy and as the result of it a new system of states emerged in terms of their competitive strength (Kukliński 2012; IMD, WEF).. Therefore, the rank of the European Union documents has increased in the field of innovativeness (e.g. Europe 2020) and their implementation allows for an increase of its position. Reflecting on the need to raise the level of innovativeness of the Polish economy it should be emphasized that the main role in the development of innovativeness is played by enterprises in cooperation with the sector of science, technology infrastructure units, financial support entities as well as government policy. Knowledge about the future intentions of entrepreneurs on how to build innovative sources of growth is not fully understood. In the meantime, it is necessary for the implementation of innovative policies in the country and in each region, as well as educational policy in the field of strategic management of enterprises and their strategy of innovativeness.

The study was inspired by concern with limited innovation in Poland's industry and the fact that the country's businesses tend not 
to be involved in the triple-helix cooperation which is requisite for knowledge transfers and innovation.

To meet these expectations, the authors conducted a NCN (National Science Center) research project in the years 2010-2012 using the survey method among 259 manufacturing companies in Greater Poland using random-proportional selection. The questionnaire consisted of three parts. The first concerned the innovative activity of enterprises and the second one referred to the barriers to the development of innovativeness and how to reduce them. The results of these parts have already been published in the form of articles (Skawińska, Zalewski 2014, Zalewski, Skawińska 2014).

The aim of this study (Part 3) is to identify the future plans for the activities of enterprises in terms of the growth of innovativeness. To realize the aim of this study the following methods were used: comparative method, description method, basic statistical techniques, cross analysis, cause and effect analysis, and visualization. The respondents included individuals preparing the GUS PNT02 report related to innovativeness, and so they were rather competent people. Greater Poland region is characterized by a relatively high level of economic development and the analysis of the future directions of innovative activities of enterprises can form the basis for generalizations.

\section{The theoretical framework and research method}

The theoretical framework for this research has been endogenous growth theory, particularly resource-based model of business theory. A key role was also played by the complexity economics theory, including institutional economics, sustainable growth theory and the new innovation theory based on the fundamental transformation of businesses (Prahalad, Krishnan 2010).

The research has been broken down into several stages, one of which was sample selection. The research sample covers the Section $\mathrm{C}$ businesses (industrial processing enterprises) which took part in the 2010 PNT-02 survey ${ }^{1}$. The sample comprised roughly $25 \%$ of the companies which submitted their innovation reports in 2012 - these were selected randomly with account taken of:

- their headcounts (10-49, 50-249, 250-499, 500 and above),

- their distribution among Section C categories (categories 10-33).

1 PNT-02 is an industrial innovation report prepared by industry for the Polish Central Statistical Office. 
As part of the survey, questionnaires have been sent to over 1000 randomlyselected small, medium-sized and large industrial processing enterprises from the Region of Wielkopolska. The survey form comprised unambiguous statements and indications. An overwhelming majority of the questions are compound with multiple-variant options and closed-ended. Some of the questions are semi-close-ended.

The respondents submitted a total of 259 correctly filled out complete response forms. The largest number of such responses (as specified below in parentheses) came from enterprises in the categories of finished metal products (26), furniture (23), machinery and equipment not elsewhere classified (22), food products (24) and products of wood and cork (22).

In terms of headcount, most responses came from small (116) and mediumsized enterprises (92). Completed survey forms were also received from 44 companies employing more than 250 workers, including 17 large enterprises with headcounts in excess of 500. Completed forms were also returned by 7 micro-enterprises.

\section{The analysis of future markets for the growth of innovation}

Strategic approach in the functioning of companies allows recognizing future opportunities and threats to innovative activity. It provides an opportunity to pass the competition and create conditions for cooperation with surrounding entities in the development of innovativeness. In order to identify the state of knowledge about innovativeness resulting from this approach, respondents had to assess the four aforementioned most absorbent product and service markets regarding innovativeness in the future.

In the light of the provided replies (question 1) the greatest opportunities for growth of innovation in the next five years will emerge in the following markets (in order of the \% of responses):

- technology and organic products and energy efficient products - 71,

- new markets (e.g. design, intelligent transport) - 25,

- social services, health and education - 23,

- products and services for the elderly - 16.

It is particularly important for demographic reasons to learn the interests of manufacturers regarding products for the elderly and services of socioeducational character. The number of replies provided and their distribution between the sections indicate that these concerns are limited (table 1). Only the representatives of some industries such as the manufacturing of food products,

Identification of future activities

of enterprises regarding the growth 
textiles, basic pharmaceuticals, automotive or furniture, expressed more interest in these problems.

Such opinions point to the underestimation of products and services of social and health character as well as those intended for the elderly. Due to the permanent demographic changes in Europe and Poland and worldwide trends in the behavior of the so-called Y-consumers (people of retirement age) sensitive to the effect of the show and health-promoting lifestyle, they will become increasingly important. They should therefore act as a source of inspiration for many companies regarding innovativeness in the near future (Skawińska 2009).

Table 1. The number of indications of future markets by respondents of enterprises by Polish Classification of Activities (PKD) for the growth of innovations

\begin{tabular}{|c|c|c|c|c|c|c|c|}
\hline \multirow{2}{*}{ Section } & \multicolumn{2}{|c|}{ Number } & \multirow{2}{*}{ Name } & \multirow{2}{*}{ Section } & \multicolumn{2}{|c|}{ Number } & \multirow{2}{*}{ Name } \\
\hline & $a^{*}$ & $b^{*}$ & & & $a^{*}$ & $b^{*}$ & \\
\hline 10 & 4 & 8 & food products & 22 & 2 & 1 & rubber and plastic products \\
\hline 11 & 1 & - & beverages & 23 & 3 & 4 & $\begin{array}{l}\text { of other non-metallic } \\
\text { mineral products }\end{array}$ \\
\hline 12 & - & - & tobacco products & 24 & 2 & 2 & metals \\
\hline 13 & - & 5 & textiles & 25 & - & 5 & $\begin{array}{l}\text { fabricated metal products } \\
\text { (excluding machinery) }\end{array}$ \\
\hline 14 & 1 & 2 & clothing & 26 & - & - & $\begin{array}{l}\text { Computer, electronic and } \\
\text { optical products }\end{array}$ \\
\hline 15 & - & 1 & leather and leather products & 27 & 1 & 2 & electrical devices \\
\hline 16 & 4 & 6 & products of wood and cork & 28 & 2 & 2 & $\begin{array}{l}\text { machinery and equipment } \\
\text { not classified anywhere else }\end{array}$ \\
\hline 17 & 2 & 3 & paper and paper products & 29 & 2 & 4 & $\begin{array}{l}\text { motor vehicles, trailers, } \\
\text { without motorcycles }\end{array}$ \\
\hline 18 & 3 & 2 & $\begin{array}{l}\text { printing and reproduction } \\
\text { from the IT media. }\end{array}$ & 30 & - & 1 & other transport equipment \\
\hline 19 & & & $\begin{array}{l}\text { manufacture of coke and } \\
\text { refined petroleum products }\end{array}$ & 31 & 3 & 2 & furniture \\
\hline
\end{tabular}




\begin{tabular}{|c|c|c|c|c|c|c|c|}
\hline 20 & 1 & 3 & $\begin{array}{l}\text { chemicals and chemical } \\
\text { products }\end{array}$ & 32 & 3 & 1 & other products \\
\hline 21 & 5 & 4 & $\begin{array}{l}\text { basic pharmaceutical } \\
\text { products and medicines }\end{array}$ & 33 & 1 & 1 & $\begin{array}{l}\text { repair, maintenance and } \\
\text { installation of machinery } \\
\text { and equipment }\end{array}$ \\
\hline
\end{tabular}

Explanation: a - products and services for the elderly, $\mathrm{b}$ - social, educational, health services

Source: own study based on research results

Significant demographic changes have been taking place in Poland. The population forecast according to biological age groups is shown in Figure 1. It implies an increasing reduction in the number of total populations and in the age category 17-64 years and the growth of population aged $65+, 80+$ - especially after the year 2020 .

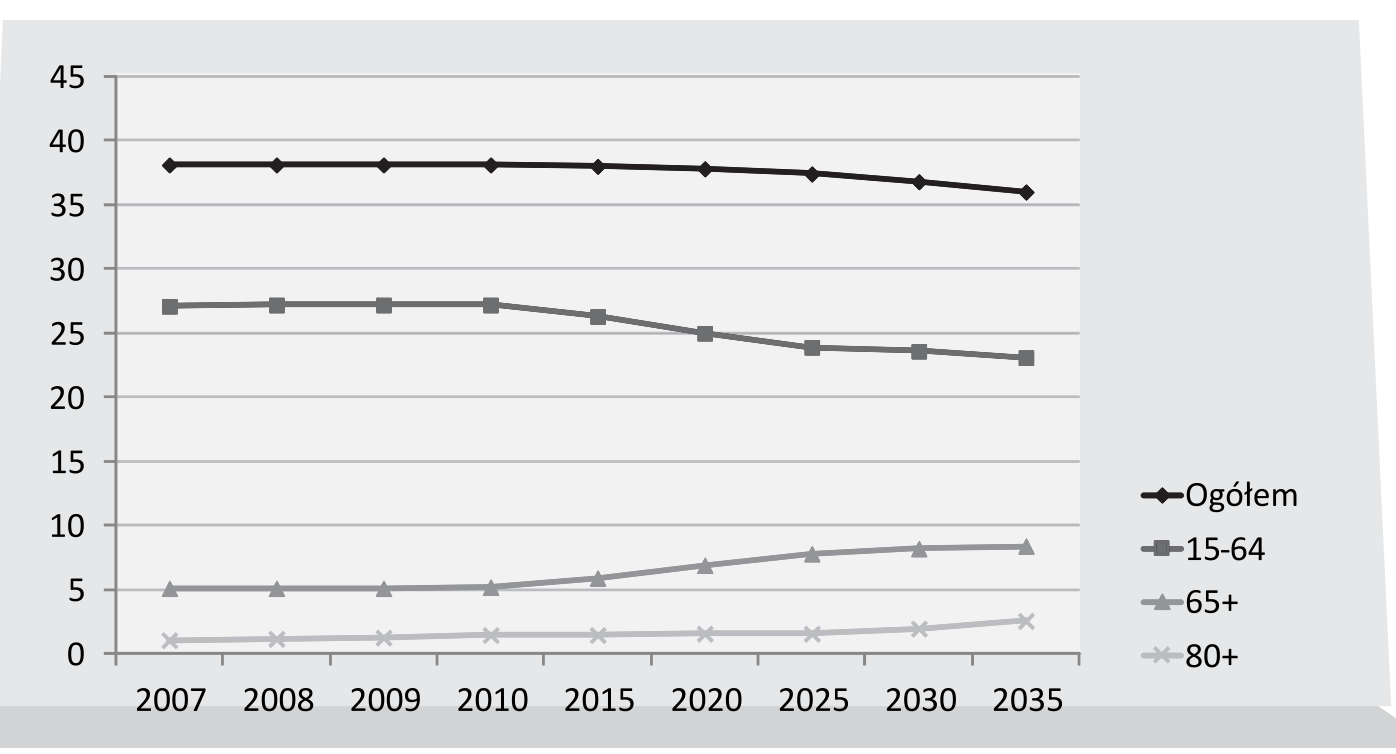

Figure 1. Population forecast according to age groups in Poland

Source: prepared on the basis of Central Statistical Office forecast, 2009

As a result of the projected demographic changes some regularity can be formulated below.

1. The number of people of working age decreases in general population. In 2006

Identification of future activities of enterprises regarding the growth 
it amounted to 24.5 million people and in 2020 it will decrease to 22.5 and 21.3 million in 2030. The forecast assumes the aging of population and the increase in the share of unproductive and immobile members.

2. The number of elderly people increases along with life expectancy for both men and women. The share of the population of retirement age, i.e. men 65 years old and more, and women aged 60 years and above in 2006 amounted to $15.8 \%$ of the total population. Demographic forecast indicates that the participation rate of this population group will in 2015 amount to - 19.4\%, in $2020-22.1 \%$, in $2030-25.2 \%$, and in 2035 -26.7\% (CSO Forecast 2009).

The shrinking number of total and working population poses a challenge for the economy which will have to meet the needs of residents through an increase in innovation. Above all, the aging population will trigger new needs in terms of products and services for a group of seniors. These problems have not been given due attention so far. But also the development of new trends in the behavior of young people (sport, leisure, tourism, ecology) forces for new products. In society it is favored by an increased time off work (Borowska 2010, Lipski 2008).

It is also surprising that only $80 \%$ of respondents declare the knowledge of regional innovation strategy. This shows a need for more effective communication of this strategy's goals, principles, etc. This questions efficiency, intensity and the scope of communication of existing conferences and trainings related to the spread of this strategy and its role.

\section{Future activities of companies in the development of competitive advantage through innovations}

While setting out innovative activities influencing competitive advantage in the market in the next years (question 2) the representatives of companies most often selected conservative options. The replies regarding main activities in this area are presented in table 2 .

Table 2. The main innovative activities that will shape the competitive advantage in the near future, in the opinion of the respondents

\begin{tabular}{c|l|c}
\hline $\begin{array}{c}\text { Choice } \\
\text { Options }\end{array}$ & \multicolumn{1}{|c|}{ Most often selected types of activities } & $\begin{array}{c}\text { Number of } \\
\text { indications }\end{array}$ \\
\hline A & $\begin{array}{l}\text { modifications to existing products, processes, services, towards an } \\
\text { increase in quality }\end{array}$ & 196 \\
\hline
\end{tabular}




\begin{tabular}{c|l|c} 
B & reduction in the manufacturing costs of present products & 183 \\
\hline C & better co-operation with clients & 124 \\
\hline D & $\begin{array}{l}\text { new business models, organizational structures, marketing tools, } \\
\text { distribution channels, }\end{array}$ & 79 \\
\hline E & increase in new applications of existing products, processes, services, & 78 \\
\hline
\end{tabular}

Source: own study based on research results

Among other innovative activities not reflected in Table 2 it should be noted that only 25 representatives of companies chose collaboration with competitors for the formation of competitive advantage in the market. What's more, only 7 respondents identified the option to 'limit the functionality of existing products' - the so-called disruptive innovation (Christensen, 1997; Gilbert 2003). The presented choices of innovative actions show a fairly traditional approach to building competitive advantage. The increase in the quality of products, modifications or improvements, reducing manufacturing costs and improving co-operation with clients are all widely regarded as important. These are, however, advantages for the past, or at most - present. The responses indicate the underestimation of cooperation with competitors (Hamel, Prahalad, 1999; Cygler 2009) or the benefits arising from the formation of alliances or business clusters (Skawińska, Zalewski 2009). Similarly, the need to create new business models, new organizational structures, and methods of distribution is not fully appreciated. There are large markets in developing countries which seek cheaper products with slightly limited features. These requirements widely discussed in the literature (Hamel, Prahalad, 1999; Christensen, 1997; Gilbert 2003) are not recognized by the representatives of the surveyed companies.

Many interviewed companies chose a couple of response options. Of the 196 companies that pointed to ,the modification of existing products', 155 chose option $C$,reducing the manufacturing costs of existing products', including 99 who chose the option F ,better co-operation with the client', while 13 companies among the 196 only chose variant F. Since the option A was indicated by 196 respondents it proved to be the most important one for the companies. Therefore, those groups that chose it the most numerously (over 10 responses) were selected from the classification section of the industry and their structure is shown in table 3 .

It should be noted that, based on the data in Table 3, only section 21 belongs to a high manufacturing technique. Despite the considerable fragmentation of 
the entities and their small share in the domestic market most operators in the future prefer to engage in conservative competitive actions.

New business models, new distribution methods and new organizational structures remain underestimated. The question arises why? Therefore the respondents were asked the following question: ,what actions have been undertaken for the formation and strengthening of innovativeness in recent years' (question 3).

Table 3. The share of enterprises choosing 'modification of products, processes and services'

\begin{tabular}{c|c|l|c|c|l}
\hline Section & $\%$ & Section Name & Section & $\%$ & Section Name \\
\hline 10 & 75,0 & food products & 21 & 90,5 & $\begin{array}{l}\text { basic pharmaceutical products } \\
\text { and medicines }\end{array}$ \\
\hline 13 & 92,3 & textiles & 27 & 44,4 & electrical devices \\
\hline 16 & 93,8 & products of wood and cork & 28 & 67,9 & $\begin{array}{l}\text { machinery and equipment not } \\
\text { classified anywhere else }\end{array}$ \\
\hline 17 & 58,8 & paper and paper products & 29 & 48,3 & $\begin{array}{l}\text { motor vehicles, trailers, without } \\
\text { motorcycles }\end{array}$ \\
\hline 20 & 60,0 & $\begin{array}{l}\text { chemicals and chemical } \\
\text { products }\end{array}$ & 31 & 54,8 & furniture \\
\hline
\end{tabular}

(see Table 2, option A) as the main source of competitive advantage in the various branches of Polish Classification of Activities

Source: own study based on research results

Among the 13 directions of innovative activities proposed in the questionnaire also the most traditional ones were selected most frequently (Table 3). Replies can be divided into three groups of actions in terms of number of indications. The most numerous among them relate to quality, competitiveness and cooperation with customers. In most developed economies these problems have been resolved, inter alia, through quality management systems such as ISO 9000, TQM concept, standardization of products, etc. In a market economy the cooperation with the customer and continuous improvement of quality are the incremental innovation growth factors (Zalewski 2013). Replies given to those questions are in line with the results of the analysis of the PNT-02 questionnaires (Talaga 2013). The role of the quality and diversity of products 
to compete in global markets was discussed by M.E. Porter already in the eighties and later (Porter, 1985, 1998).

The lowest number of responses was given to actions which in developed countries and the era of the knowledge economy are treated as important and are used more frequently. These include the analysis of market risk for innovations, functional flexibility of workers (the possibility of their use on different positions), and permanent ways to bind future users with the work of innovative companies (table 4).

Table 4. Respondents' perception of the validity of measures to enhance innovativeness

\begin{tabular}{|c|c|}
\hline Activities & $\begin{array}{l}\text { Number of } \\
\text { indications }\end{array}$ \\
\hline \multicolumn{2}{|l|}{ The most common } \\
\hline - an increase in quality & 210 \\
\hline - better customer service & 192 \\
\hline - an increase in competitiveness & 151 \\
\hline - better service & 120 \\
\hline \multicolumn{2}{|l|}{ Of average intensity } \\
\hline $\begin{array}{l}\text { - monitoring sources of innovation (new knowledge, changes in the } \\
\text { market structure...) }\end{array}$ & 111 \\
\hline - cooperation with foreign companies & 108 \\
\hline - knowledge and information management system & 90 \\
\hline - motivating employees to come up with innovative ideas & 89 \\
\hline \multicolumn{2}{|l|}{ Less frequently used } \\
\hline - analysis of market risk for implemented innovations & 76 \\
\hline - moving workers into different positions and different departments & 75 \\
\hline - creation of teams to implement innovative projects & 66 \\
\hline - imitating products & 60 \\
\hline $\begin{array}{l}\text { - inclusion of future users in a company's innovative activities } \\
\text { (prosumption) }\end{array}$ & 51 \\
\hline
\end{tabular}

Source: own study based on research results 
The central position in the number of indications (from 90 to 110) deals with activities aimed at monitoring the sources of innovation, collaboration with foreign firms, knowledge / information management and motivating employees to submit ideas. Monitoring the sources of innovation by enterprises can be described as moderately intense.

Among the activities less widely used and less well-known in Poland one should pay attention to prosumption and 'customer driven innovation'. The term prosumption is a combination of parts of the following words: pro-duction and con-sumption and means that a consumer of goods is also their co-producer. The idea is based on the concept of innovative and entrepreneurial consumption and is sometimes referred to as "smart consumption". It is quite well described in the literature (Prahalad, Ramaswamy 2005, von Hippel 2005; Jacyna 2006).

On the other hand, 'customer driven innovation' means the inclusion of consumers and customers into the process of creating and improving innovation (Prahalad, Ramaswamy 2005, von Hippel 2005). Thus, the need arises to educate employees of companies on the topic. In this regard, business environment organizations can be helpful. This is why the representatives of the companies replied to three questions about the monitoring of sources of innovation via the Internet:

- the possibility of obtaining information about innovations from the Internet (current status),

- whether a company uses internet platforms for gaining knowledge about innovations (hazard elimination methods),

- monitoring of sources of innovation (actions for the future).

The comparative analysis of responses suggests that their complete compliance occurs only 32 times (among 259 respondents) with affirmative responses, and 60 times with negative ones and double compliance occurs with affirmative responses 42 times. This may point to the vulnerability of awareness among the respondents of activity chain in the development of innovative enterprises.

There exists one inconsistency with the results of the PNT-02 questionnaires (Talaga 2013) which shows that invariably for a decade the main sources of innovation information have remained within enterprises. On the other hand, these results suggest that companies turn to external sources of information (the Internet, platforms).

Similarly, cooperation with foreign companies can take various forms, among others, with FDI-s. Only 25 representatives of companies (about 10\%) answered the question about the degree of the impact of FDI on the growth of innovativeness in the industry and they believe that it is high. In contrast, the results shown in Table 4 are more favorable. The representatives of 108 
companies declare that they have initiated or continued their cooperation with foreign companies. This may serve as a harbinger of improvement. This group of indications also includes knowledge management systems in companies and motivating employees to submit innovative ideas.

There is a visible lack of understanding and knowledge among the respondents about the activities of freelancers who integrate the achievements of science with the needs of the business (Zalewski 2010, Millar, Demaid, Quintas 1997) and the so-called 'business angels' (Skawińska 2012 Kotowicz Jawor 2012, Leviathan). For more than $80 \%$ of the respondents these terms are not clear and they do not have their own opinion about their role. The freelancers are people who form the bridge between business needs and the knowledge and the potential of scholars. These are the people who are aware of the needs and capabilities of others. They try to search scientific journals, conferences, symposia, visit universities, etc. for such values which have potential importance for the development of techniques and technologies and can be useful in the economy. Among the scientific community these values are often underestimated. On the other hand, by penetrating the economic environment they are able to learn current demand for new solutions, methods and innovations. By acting in a specific industry they can associate supply with demand and liaise in contact between science and industry. Of course, they are remunerated for their services.

There are numerous entities in the process of providing financial support to the development of innovativeness (banks, business angels and others). Business angels "are interested in smaller innovative investment projects in which they possess confidence. For them the prospect of partnership is important" (Skawińska 2012). They make available their business contacts, knowledge and skills and capital already at the early stages of investment, i.e. during the seeding of innovations (seed or start-up). In Poland their role is now growing.

\section{Summary}

The 2011 study refers to micro-enterprises, SMEs and large enterprises considered by WUS (Statistical Office) in Szczecin as innovative in the industry of Greater Poland. As the sample of companies was quite large - 1,000 units, the detailed results of the analysis may provide basis for the generalization of such entities' behavior in Poland. They also allow to attempt to determine the future of such behavior in the innovative activity of companies which in the literature are called the 'creative diffusion' of innovation. One can even try to determine the future development model of the innovative activity of companies now

Identification of future activities

of enterprises regarding the growth

of innovativeness 
recognized as an innovative variant optimizing the use of existing potential for innovation / positive variant / and stagnant model, while maintaining the driving forces behind the current level.

The following cognitive and applicative conclusions have been drawn arising from the study on the future activities of enterprises in the growth of innovation.

1. Within the next 5 years opportunities to boost innovativeness in companies will be sought in the development of technology and organic product and energy-efficient markets. The issues of innovations taking into account demographic processes and social service markets and new global trends in the development of smart markets are not fully appreciated.

2. In the future, competitive advantage of innovative activities, as envisaged by the respondents, will be based on the sources of quality, cost and collaboration with customers. In the light of KBE challenges these measures are conservative and traditional. In contrast, new sources, such as changing the structure of the organization (alliances, clusters, new business models, new marketing instruments, cooperation with a competitor) attract little attention, although they are being noticed.

3. This conclusion corresponds with respondents' perception of the validity of prospective measures to enhance innovativeness. In other words, to enhance the quality, better customer service and increased competitiveness. But also, although with less intensity of indications, it will refer to monitoring the sources of innovation, cooperation with foreign companies, knowledge and information management and motivating employees in a better way to submit innovative proposals.

4. Future actions foreseen by the representatives of the companies probably are a step "forward" in the light of the gap of innovation in Poland, but they are not sufficient. Quite small remains the emphasis on cooperation, prosumption and structural changes. The potential for innovation in enterprises inherent in human and social capital is associated with the policy of the State regarding formal institutions and instruments of fiscal and monetary policy. So far, it has remained largely hidden.

In conclusion, the process of innovation development in Poland on the example of survey replies provided by the representatives of companies from Greater Poland involves some administering, inter alia, through the European funds. Meanwhile, this process should be managed with regard to strategic thinking.

Acknowledgement. The research has been conducted in years 2010-2012 in project NCN nr 2657/B/H03/2010/39. 


\section{Summary}

Identification of future activities of enterprises regarding the The article contains the results of a survey conducted among 259 companies in Greater Poland from 1000 of those entities which had received the questionnaire using a random-proportional selection. This paper's structure consists of three parts theoretical one and two which characterize empirical work. The first part interprets the future market assessment regarding the growth of innovations in companies. The second part includes an analysis of innovative actions in the near future (as indicated by enterprise representatives) in the development of competitive advantages and their perceived importance. Both cognitive and applicative conclusions are present in the summary.

Keywords: innovativeness, future markets, competitive advantage of companies.

\section{Streszczenie}

Identyfikacja przyszłych działań przedsiębiorstw w zakresie wzrostu innowacyjności

Artykuł zawiera wyniki badań ankietowych przeprowadzonych wśród 259 przedsiębiorstw w Wielkopolsce, spośród 1000 tych jednostek, do których skierowano formularz z zastosowaniem doboru losowo-proporcjonalnego. Struktura pracy składa się z podstaw teoretycznych i charakterystyki metody badawczej oraz dwóch części badań empirycznych. W pierwszej zinterpretowano ocenę rynków przyszłości dla wzrostu innowacji w firmach, wykonaną przez respondentów. W drugiej części przeprowadzono analizę wskazanych przez przedstawicieli przedsiębiorstw, działań innowacyjnych w najbliższej przyszłości, w kształtowaniu przewag konkurencyjnych oraz postrzeganej ich ważności. W podsumowaniu zawarte zostały wnioski poznawcze i aplikacyjne.

Słowa

kluczowe: innowacyjność, rynki przyszłościowe, przewaga konkurencyjna przedsiębiorstw. 


\section{Literature}

1. Borowska A. (2010). Problemy ludzi III wieku w aspekcie czasu wolnego. Economy and Management, 2.

2. Christensen C.M. (1997). The innovator's dilemma, Mc Graw-Hill, New York.

3. Cygler J. (2009). Kooperencja przedsiębiorstw; czynniki sektorowe I korporacyjne, SGH Warszawa.

4. Europa 2020. A strategy for smart, sustainable and inclusive growth. Brussels 3.3. 2010. 5.

5. COM (2010/2020). http//ec.europa.eu/europe2020/index_en.htm

6. Gilbert (2000). The disruptive opportunity, MIT Sloan Management Review, Summer.

7. Hamel G., Prahalad C.K. (1999). Przewaga konkurencyjna jutra, Business Press Warszawa.

8. von Hippel E. (2005). Democratizing innovation, MIT Press London.

9. IMD (2013). World Competitiveness Yearbook, Institute for Management Development, Lozanna.

10. Jacyna E. (2006). Miejsce prosumpcji w globalnej gospodarce rynkowej, Zeszyty Naukowe Politechniki Poznańskiej, Organizacja i Zarządzanie, 42.

11. Kotowicz-Jawor J. (2012). Wpływ funduszy strukturalnych UE na transfer wiedzy do przedsiębiorstw. Wyd. Instytut Nauk Ekonomicznych, PAN, Warszawa.

12. Kukliński A. (2012). Rekonfiguracja sceny globalnej XXI wieku, w: Forum myśli strategicznej, Biuletyn Zarządu Krajowego PTE nr. 2(56), Warszawa.

13. Lipski A. (2008). Czas wolny w czasie życia, Ruch Prawniczy, Ekonomiczny i Socjologiczny LXX (4).

14. Lewiatan Business Angels (LBA) www.lba.pl

15. Millar J., Demaid A, Quintas P. (1997). Trans-organizational Innovation: A framework for Research, Technology, Analysis\&Strategic Management, 9(4).

16. Porter M.E. (1985). Competitive Advantage, Free Press. New York.

17. Porter M.E. (1998). Strategia konkurencji. Metody analizy sektorów i konkurentów. PWE Warszawa.

18. Prahalad C.K., Krishnan M.S. (2010). Nowa era innowacji Wydawnictwo Profesjonalne PWN Warszawa.

19. Prahalad C.K., Ramaswamy V. (2005). Przyszłość konkurencji, PWE Warszawa.

20. Prognoza ludności na lata 2008 - 2035. GUS Warszawa 2009.

21. Skawińska E. (2009). Wpływ warunków demograficznych na marketingowe zarządzanie przedsiębiorstwem przyszłości, Marketing i Rynek, 5. 
22. Skawińska E., Na spotkanie Aniołów Biznesu - kilka kroków w realizacji innowacyjnego pomysłu, www.innopena.pl/e-learning

23. Skawińska E., Zalewski R.I. (2009). Klastry biznesowe w rozwoju konkurencyjności i innowacyjności regionów. Świat - Europa - Polska, PWE Warszawa.

24. Skawińska E., Zalewski R.I. (2014). Innowacyjność przedsiębiorstw - bariery i sposoby ich ograniczania (na przykładzie Wielkopolski) w: Problemy rozwoju regionalnego, PTE, Oddz. Zielona Góra (w druku).

25. Talaga Ł. (2013). Innowacyjność przedsiębiorstw przetwórstwa przemysłowego w Wielkopolsce w latach 2002-2010 w: Nowe otwarcie na innowacje, red. R.I. Zalewski, Komisja Nauk Towaroznawczych PAN, Poznań 2013.

26. WEF. The Global Competitiveness Report 2013 - 2014 http://www. weforum.org/issues/global-competitiveness

27. Zalewski R.I. (2010). Czynniki jakościowe w modelu wzrostu a innowacyjność, w: Innowacyjność przedsiębiorstwa a jakość produktów, red. R.I. Zalewski i R. Zieliński, Wydawnictwo ITE - PIB Radom.

28. Zalewski R.I. (2013a). Czy system zarządzania jakością wzmacnia aktywność innowacyjną przedsiębiorstw? Wydawnictwo GSW Milenium (w druku).

29. Zalewski R.I., Skawińska E. (2014). Aktywność innowacyjna przedsiębiorstw w Wielkopolsce, w: Monografii pod red. E. Bojar, TNOiK Dom Organizatora, Torun (w druku). 